\title{
PENGARUH HARD SKILL DAN SOFT SKILL TERHADAP KINERJA KARYAWAN PT. TELKOM SUMATERA
}

\author{
Novita Sari Siahaan \\ Alumni Jurusan Manajemen Fakultas Ekonomi Universitas Negeri Medan \\ Humisar Sihombing \\ Dosen Jurusan Manajemen Fakultas Ekonomi Universitas Negeri Medan
}

\begin{abstract}
This study aims to determine the effect of Hard Skill and Soft Skill Against Employee Performance PT. Telkom Sumatera. The sample in this research is all employees of PT. Telkom Sumatra as many as 67 people. The test used is instrument test and classical assumption test. Hypothesis testing using multiple linear regression analysis, $t$ test and $F$ test. From result of validity test obtained $r_{\text {count }}>r_{\text {table }}$ for each question item and reliability test questionnaire obtained by alpha cronbach each variable that is 0,826 for variable of Hard Skill (X1), 0,897 for variable of Soft Skill (X2) and 0,885 for Employee Performance variable Y). This value is greater than the significant level of $r_{\text {table }} i$ is 0.313. Data analysis of each variable obtained by regression equation $Y=14,154+0,330 X 1+0,387 X 2$ $+e$. Obtained R2 equal to 0,521 which means X1, X2, explain the effect to $Y$ variable equal to 52,1\% while the rest influenced by other factor. The partial test ( t test) of each independent variable has an effect on the dependent variable with the research significance is smaller than 0,1, and the result of simultaneous test (test $F$ ) calculation is 34,784 with $F_{\text {table }} 2,38$ which means $F_{\text {count }}>F_{\text {table }}$ with level if significant $(\alpha)<0,1$, which means the accepted hypothesis is Hard Skill and Soft Skill has jointly significant effect on Employee Performance PT. Telkom Sumatera.
\end{abstract}

Keywords: Hard Skill, Soft Skill, Employee Performance

\section{PENDAHULUAN}

Dewasa ini, industri telekomunikasi di Indonesia tampak semakin berkembang.Hal ini dapat dilihat dari pertumbuhan perusahaanperusahaan telekomunikasi seperti: PT. Telkom, PT. XL Axiata, PT. Indosat, Smartfrend, Tri (3), dan lainlain. Meningkatnya pertumbuhan tersebut membuat setiap industri telekomunikasi semakin bersaing dalam memasarkan produkproduknya. Dari hasil persaingan ternyata PT. Telkom, PT. XL Axiata dan PT. Indosat tampil lebih unggul dibandingkan perusahaan telekomunikasi lainnya yang menguasai hampir $85 \%$ masyarakat Indonesia. Perbandingan ketiga perusahaan tersebut dapat dilihat dalam gambar sebagai berikut:

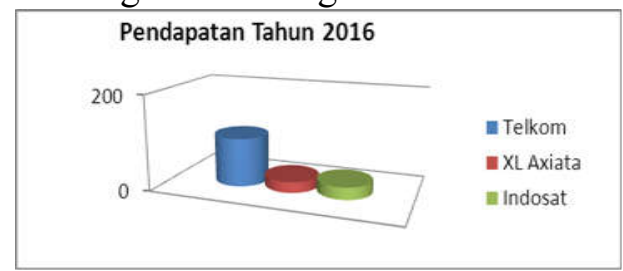

Gambar 1. Pendapatan PT. Telkom,PT. XL Axiata, PT. Indosat, 2016 
Jumlah Pelanggan Tahun 2016

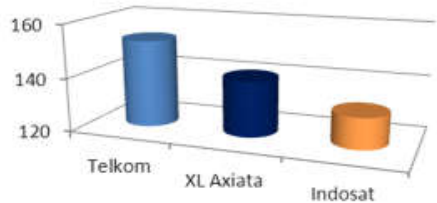

Gambar 2. Jumlah PelangganPT. Telkom, PT. XL Axiata, PT. Indosat, 2016

Keberhasilan PT. Telkom tersebut tidak terlepas dari berbagai faktor yang dimiliki perusahaan termasuk peran Sumber Daya Manusia (karyawan). Peran yang dimaksud adalah bagaimana kinerja karyawan dalam melaksanakan tugas dan tanggung jawab sesuai dengan beban kerja yang diberikan kepadanya. Namun, jika dilihat dari kinerja karyawan PT. Telkom Sumatera ternyata masih ada beberapa kenyataan yang kurang sesuai dengan harapan diantaranya adalah sebagai berikut: rendahnya etos kerja karyawan: banyak karyawan yang tidak tepat waktu datang masuk kantor dan beberapa karyawan sering ngobrol saat jam kerja, pelaksanaan tugas kantor yang sering tertunda, rendahnya pengetahuan IPTEK sebahagian karyawan, kurangnya interaksi karyawan: dimana beberapa karyawan kurang peduli dengan rekan kerja, tingkat pendidikan yang belum merata, beberapa karyawan masih sulit meningkatkan kompetensi: dimana beberapa karyawan meskipun telah bekerja selama 30 tahun masih tetap melakukan pekerjaan yang sama (Wahyuni,2016).

Berdasarkan pendapat diatas, hal ini dijadikan fenomena bahwa kinerja karyawan pada PT. Telkom Sumatera masih rendah.Menurut Mangkunegara (2004:67) kinerjaadalah hasil kerja secara kualitas dan kuantitas yang dicapai oleh seorang pegawai dalam melaksanakan tugasnya sesuai dengan tanggung jawab yang diberikan kepadanya. Kinerja karyawanmerupakan suatu hal yang sangat penting dalam upaya perusahaan untukmencapai tujuannya (Yanti, dkk. 2010: 8). Dengan kata lain, bila kinerja karyawan baik, makakemungkinan besar kinerja perusahaan juga baik.

Banyak faktor yang mempengaruhi kinerja karyawan, salah satunya adalah faktor Hard Skill karyawan.Hardskill karyawan adalahpengetahuan dan kemampuan teknis yang dimiliki karyawan (Islami, 2012). Hasil penelitian Rahayu (2011) menyimpulkan bahwa hardskill sangat mempengaruhi kinerja karyawan. Kemampuan hardskill yang tinggi akan membantu karyawan dalam pencapaian standar dan target kerja yang telah ditetapkan.

Salah satu indikator hardskill karyawan adalah latar belakang pendidikan yang dimiliki karyawan. Kondisi tingkat pendidikan karyawan pada PT. Telkom Sumatera adalah sebagai berikut:

Tabel 1. Tingkat Pendidikan

Karyawan

\begin{tabular}{|l|c|c|c|}
\hline $\begin{array}{c}\text { Tingkat } \\
\text { Pendidikan }\end{array}$ & $\begin{array}{c}\text { Jumlah } \\
\text { Karyawan }\end{array}$ & Persentasi & Kategori \\
\hline Sarjana & 96 & $47,0 \%$ & Tinggi \\
\hline Diploma & 60 & $29,2 \%$ & Sedang \\
\hline SLTA & 48 & $23,4 \%$ & Rendah \\
\hline SD & 1 & $0,4 \%$ & Rendah \\
\hline \multicolumn{1}{|c|}{ Jumlah } & $\mathbf{2 0 5}$ & $\mathbf{1 0 0} \%$ & \\
\hline
\end{tabular}

Sumber: PT. Telkom SumateraTahun 2016

Dari tabel 1. dapat dijelaskan bahwa dari 205 orang karyawan, 96 orang $(46,8 \%)$ lulusan Sarjana dalam kategori pendidikan tinggi,60 orang (29,2\%) lulusan Diploma dalam kategori pendidikan sedang,dan 48 
orang $(29,0 \%)$ lulusan SLTA serta 1 orang $(0,4 \%)$ lulusan SD dalam kategori pendidikan rendah. Dengan demikian dapat disimpulkan bahwa tingkat pendidikan karyawan PT. Telkom Sumatera tergolong dalam kategori pendidikan tinggi.

Melihat tingginya tingkat pendidikan karyawan PT. Telkom Sumatera dapat dijadikan sebuah fenomena bahwa semakin tinggi tingkat pendidikan karyawan maka semakin tinggi pengetahuan dan kemampuan karyawan dalam bekerja yang nantinya akan meningkatkan kinerja karyawan tersebut. Menurut Eva, dkk (2012) Kualitas pekerjaan berhubungan dengan pendidikan dan kecerdasan, dimana peningkatan pendidikan dan kecerdasan akan meningkatkan cara berfikir secara kritis sehingga lebih mampu mengekspresikan keinginan dan merespon setiap permasalahan yang muncul.

Selain faktor hardskill karyawan ada juga faktor lain yang diperkirakan mempengaruhi kinerja karyawan yaitu faktor softskill karyawan. Softskill karyawan adalah keterampilan seseorang dalam berhubungan dengan orang lain dan keterampilan dalam mengatur dirinya sendiri yang mampu mengembangkan pekerjaan secara maksimal (Sutikno, 2009). Hasil penelitian Islami (2012) menyimpulkan bahwa softskill berpengaruh terhadap kinerja karyawan. Softskill dilihat dari sikap karyawan saat bekerja yang diukur dari tanggung jawab, kerjasama, komunikasi dan bagaimana karyawan membangun hubungan baik terhadap atasan, rekan kerja maupun bawahan.

\section{KAJIAN PUSTAKA Kinerja Karyawan}

Kesuksesan suatu organisasi dilihat dari keberhasilan organisasi tersebut mencapai tujuannya.Salah satu faktor keberhasilan sebuah organisasi tidak terlepas dari kinerja sumber daya manusia (karyawan) organisasi tersebut.Kinerja adalah suatu hasil kerja secara kualitas dan kuantitas yang dicapai oleh seorang karyawan dalam melaksanakan tugasnya sesuai dengan tanggung jawab yang diberikan kepadanya (Mangkunegara, 2000: 67).

Menurut Hasibuan (2001:34), kinerja atau prestasi kerja adalah hasil kerja yang dicapai seseorang melaksanakan tugas-tugas yang dibebankan kepadanya yang didasarkan atas kecakapan, pengalaman, dan kesungguhan serta waktu. Menurut Rivai dan Basri (2005: 50), kinerja adalah hasil atau tingkat keberhasilan seseorang secara keseluruhan selama periode tertentu dalam melaksanakan tugas dibandingkan dengan berbagai kemungkinan, seperti standar hasil kerja, target atau sasaran atau kriteria yang telah ditentukan terlebih dahulu atau yang telah disepakati bersama.

Selanjutnya Sedarmayanti (2007:260) mengatakan kinerja adalah hasil kerja seseorang atau sekelompok orang dalam suatu organisasi, sesuai dengan wewenang dan tanggung jawab masing-masing dalam rangka mencapai tujuan organisasi bersangkutan secara legal, tidak melanggar hukum dan sesuai dengan moral maupun etika.

\section{Hard Skill}

Hard skill adalah kemampuan teknis yang melekat atau dibutuhkan 
dalam profesi tertentu. Menurut Utomo (2010) hard skill merupakan perilaku dan keterampilan yang dapat dilihat oleh mata. Hard skill adalah pengetahuan dan kemampuan teknis yang dimiliki seseorang (Islami, 2012). Menurut Kurniawan (2012) hard skill adalah penguasaan ilmu pengetahuan, teknologi dan keterampilan teknis yang berhubungan dengan bidang ilmunya.

Hard skill sering juga disebut dengan kemampuan intelektual (intellectual ability). Menurut Robbins (2008:57) kemampuan intelektual (intellectual ability) adalah kemampuan yang dibutuhkan untuk menentukan berbagai aktivitas mental-berpikir, menalar dan memecahkan masalah.

Dunia kerja erat kaitannya dengan kecerdasan intelektual yang dimiliki seseorang. Seorang karyawan yang memiliki IQ tinggi diharapkan dapat menghasilkan kinerja yang lebih baik dibandingkan karyawan lain yang memiliki IQ rendah. Hal tersebut karena mereka yang memiliki IQ tinggi lebih mudah menyerap ilmu yang diberikan sehingga kemampuannya dalam memecahkan masalah yang berkaitan dengan pekerjaannya akan lebih baik. Contoh dari kemampuan hard skill adalah keterampilan teknis seperti keuangan, komputer dan keterampilan perakitan. Kemampuan hard skill seseorang dapat dilihat/diukur dari riwayat pendidikan orang tersebut.

\section{Soft Skill}

Soft skill adalah keterampilan lunak yang dimiliki seseorang. Menurut Sutikno (2009) soft skill adalah keterampilan seseorang dalam mengatur dirinya sendiri (intrapersonal skills) dan keterampilan dalam berhubungan dengan orang lain (interpersonal skills) yang mampu mengembangkan pekerjaan secara maksimal. Soft skill merupakan jenis keterampilan yang lebih banyak terkait dengan sensitivitas perasaan seseorang terhadap lingkungan di sekitarnya yang dapat dilihat perilaku orang tersebut seperti perilaku sopan, disiplin, keteguhan hati, kemampuan untuk bekerja sama, membantu orang lain, dan sebagainya.

Konsep soft skill sebenarnya merupakan pengembangan dari konsep kecerdasan emosional (emotional inteligence) seseorang yang merupakan kemampuan mengenali perasaan diri sendiri dan orang lain, memampuan memotivasi diri, kemampuan mengendalikan diri/mengelola emosi pada diri sendiri dalam hubungan dengan orang lain.

Soft skill bisa diartikan suatu karakter atau bakat dari seseorang yang telah ditanamkan sejak kecil atau suatu karakter yang melekat dalam diri seseorang dan menjadi ciri khas. Akan tetapi, bukan berarti keterampilan tersebut dapat diasah dan ditingkatkan seiring bertambahnya pengalaman seseorang seperti sering barinteraksi dan melakukan aktivitas dengan orang lain.

\section{METODE PENELITIAN Populasi dan Sampel}

Populasi dalam penelitan ini adalah seluruh karyawan PT. Telkom Sumatera yang berjumlah 205 orang. Dalam penelitian ini, pengambilan sampel didasarkan pada rumus Slovin untuk menentukan jumlah sampel minimal, Sugiyono (2011:87).Atas dasar ini,, maka diperoleh jumlah sampel penelitian ini ada sebanyak 67 orang. 
Defenisi Operasional dan Variabel Penelitian

Dalam penelitian ini yang menjadi variabel penelitian adalah:

1. Kinerja Karyawan (Variabel Terikat)

Kinerja karyawan adalah hasil kerja karyawan dalam pelaksanaan tugas dan kewajiban yang diembankan kepadanya dengan memenuhi standar kerja yang ditetapkan oleh perusahaan. Indikator kinerja karyawan dalam penelitian ini adalah sebagai berikut:Hasil kerja, kompetensi, pelaksanaan tugas, ketepatan waktu, komparatif, kerjasama dan perilaku.

2. Hard Skill (Variabel Bebas/ X1)

Hard skill karyawanadalah kemampuan intelektual dan keterampilan teknis yang dimiliki karyawan dan berhubungan dengan bidang pekerjaannya. Indikator Hard Skill karyawan dalam penelitian ini, yaitu: kecakapan mengerjakan tugas, pemahaman dan kemampuan verbal, kemampuanpenalaran, kecepatan perceptual, berfikirk reatif, kemampuan pengoperasian komputer dan daya ingat.

3. Soft Skill (Variabel Bebas /X2)

Soft skill karyawan adalah kemampuan yang dimiliki seseorang dalam mengatur dirinya sendiri dan keterampilan dalam membangun hubungan dengan orang lain yang dapat mengembangkan pekerjaannya. Indikator Soft Skill dalam penelitian ini adalah sebagai berikut: kemampuan beradaptasi, kemampuan kemampuan komunikasi, bersikapjujur, berperilaku adil dan manajemen diri.

\section{HASIL PENELITIAN DAN PEMBAHASAN \\ Hasil Penelitian \\ Analisis Regresi Berganda}

Pengujian melalui model regresi berganda digunakan untuk menganalisis pengaruh Hard Skill dan Soft Skill terhadap kinerja karyawan PT. Telkom Sumatera dengan model persamaan regresi: $\mathrm{Y}=\mathrm{a}+\mathrm{b} 1 \mathrm{X} 1+$ b2X2+e.

Berdasarkan hasil pengolahan data penelitian dengan menggunakan SPSS hasil persamaan regresi berganda yang diperoleh sebagai berikut. :

$$
Y=14,154+0,330 X_{1}+0,387 X_{2}
$$

Persamaan regresi dapat dijelaskan sebagai berikut :

a. Konstan sebesar 14,154 dapat diartikan bahwa Kinerja Karyawan (Y) akan bernilai sebesar 14,154 pada saat Hard Skill (X1) dan Soft Skill (X2) bernilai nol (tidak ada).

b. Koefisien regresi Hard Skill $\left(\mathrm{X}_{1}\right)$ sebesar 0,330, artinya jika Hard Skill mengalami kenaikan 1\%, maka kinerja karyawan (Y) akan mengalami kenaikan 0,330 .

c. Koefisien regresi variabel Soft Skill $\left(\mathrm{X}_{2}\right)$ sebesar 0,387, artinya jika Soft Skill mengalami kenaikan $1 \%$, maka kinerja karyawan (Y) akan mengalami kenaikan 0,387.

\section{Uji Hipotesis}

Uji Secara Parsial

Uji secara parsial (uji t) digunakan untuk melihat besarnya pengaruh antara Hard skill, soft skill secara parsial terhadap kinerja karyawan. Berdasarkan hasil uji statistik t (parsial) diperoleh hasil sebagai berikut : 
a) Nilai t hitung variabel Hard Skill (X1) $3,428>$ dari $t_{\text {tabel }}$ yaitu 0,313 dan nilai signifikan $0,001<0,1$. Hal ini berarti Hard Skill secara parsial berpengaruh positif dan signifikan terhadap Kinerja Karyawan PT. Telkom Sumatera, H1 diterima.

b) Nilai t hitung variabel Soft Skill (X2) $4,188>$ dari $t_{\text {tabel }}$ yaitu 0,313 dan nilai signifikan $0,000<0,1$. Hal ini berarti: Soft Skill secara parsial berpengaruh positif dan signifikan terhadap Kinerja Karyawan PT. Telkom Sumatera, H2 diterima.

\section{Uji Secara Simultan}

Uji Simultan atau Uji F merupakan Uji secara bersama-sama untuk menguji signifikan pengaruh variabel Hard Skill, Soft Skill Terhadap Kinerja Karyawan PT. Telkom Sumatera. Berdasarkan hasil uji statistik F (Simultan)diperoleh hasil sebagai berikut angka $F_{\text {hitung }}$ yang diperoleh dari hasil perhitungan adalah sebesar 34,784. Sedangkan $\mathrm{F}_{\text {tabel }}=2,38$.

Dengan demikian diperoleh $F_{\text {hitung }}=34,784$ dan $F_{\text {tabel }}=2,38$. Karena $\mathrm{F}_{\text {hitung }}>\mathrm{F}_{\text {tabel }}$ dan tingkat signifikan $<0,1$ yaitu $0,000<0,1$ sehingga dapat disimpulkan bahwa Hard Skill $\left(\mathrm{X}_{1}\right)$, Soft Skill $\left(\mathrm{X}_{2}\right)$ berpengaruh secara simultan Terhadap Kinerja Karyawan PT. Telkom Sumatera, H3 diterima.

\section{Pembahasan Hasil Penelitian}

Penelitian ini bertujuan untuk mengetahui pengaruh hard skill dan soft skill terhadap kinerja karyawan PT. Telkom Sumatera.Berikut pembahasan peran masing-masing variabel penelitian.

\section{Pengaruh Hard Skill terhadap Kinerja Karyawan}

Sebelum memasuki dunia kerja atau proses perekrutan karyawan, untuk melihat hard skill seseorang dapat dinilai dari riwayat hidup dan riwayat pendidikan calon pelamar tersebut. Setelah calon pelamar tersebut diterima menjadi karyawan dalam organisasi kemampuan hard skill akan dinilai dari pelaksanaan tugas dan tanggung jawabnya. Keterampilan karyawan akan menentukan pencapaian target kerja yang akan mempengaruhi meningkat tidaknya kinerja karyawan tersebut.

Berdasarkan hasil analisis yang diperoleh bahwa pengujian hipotesis hard skill terhadap kinerja karyawan menghasilkan $t_{\text {hitung }}>t_{\text {tabel }}$ sebesar $(3,428>0,313)$ dengan signifikan $(0,001<0,1)$.Dengan demikian, hard skill secara parsial berpengaruh positif dan signifikan terhadap kinerja karyawan PT. Telkom Sumatera, H1 diterima.

Hasil penelitian ini sejalan dengan hasil penelitian Widayanti (2011) yang menyatakan bahwa hard skill mempengaruhi kinerja karyawan. Dalam dunia kerja, kemampuan hard skill dapat dilihat dari kecakapan mengerjakan tugas, kemampuan intelektual, dan keterampilan teknis seperti keuangan, dan pengoperasian komputer.

PT. Telkom Sumatera, sebagai perusahaan yang bergerak dalam bidang informasi dan telekomunikasi serta penyedia jaringan telekomunikasi yang menggunakan teknologi dan inovasi yang tinggi, serta mempunyai pedoman, standar dan target kerja tertentu yang harus diimplementasikan oleh karyawan 
yang hanya dapat dicapai dengan kemempuan hard skill yang tinggi.

\section{Pengaruh Soft Skill terhadap Kinerja karyawan}

Perilaku setiap individu dalam organisasi pasti beragam atau berbeda-beda, karena individu satu satu pasti berbeda dengan individu lainnya. Kemampuan karyawan dalam membangun hubungan yang baik dengan orang lain dan kemampuan karyawan dalam mengatur dirinya sendiri sehingga karyawan tersebut diterima dan dipuji oleh atasan dan rekan kerja. Oleh karena itu soft skill dapat mengembangkan kinerja seseorang sehingga meningkatkan kinerja karyawan tersebut.

Berdasarkan hasil analisis yang diperoleh bahwa pengujian hipotesis soft skill terhadap kinerja karyawan menghasilkan $\quad t_{\text {hitung }}>\quad t_{\text {tabel }}$ sebesar $(4,188>0,313)$ dengan signifikan $(0,000<0,1)$. Dengan demikian, soft skill secara parsial berpengaruh positif dan signifikan terhadap kinerja karyawan PT. Telkom Sumatera, H2 diterima.

Hasil penelitian ini sejalan dengan hasil penelitian Chery Novita Sari (2012) yang menyatakan bahwa soft skill mempengaruhi prestasi kerja (kinerja) karyawan. Penelitian Hariyanto (2016) juga menyimpulkan bahwa semakin baik soft skill karyawan maka semakin kuat komitmen karyawan dalam bekerja sehingga mengurangi kesalahan dalam kerja. Contoh Soft skill adalah pribadi dan perilaku interpersonal yang mengembangkan dan memaksimalkan kinerja karyawan misalnya kerjasama tim, kemampuan berkomunikasi, kejujuran, motivasi, dan manajemen diri.

\section{Pengaruh Hard Skill dan Soft Skill Terhadap Kinerja Karyawan}

Dunia kerja erat hubungannya dengan kemampuan karyawan. Setiap perusahaan hanya membutuhkan tenaga kerja yang terampil dan berdaya saing untuk mencapai tujuan organisasi. Tenaga kerja yang terampil dan berdaya saing tersebut dipengaruhi oleh kemampuan hard skill dan soft skill yang dimiliki karyawan.

Berdasarkan hasil analisis yang diperoleh melalui uji $F$ untuk mengetahui pengaruh hard skill dan soft skill secara bersamaan terhadap kinerja karyawan maka diperoleh $\mathrm{F}$ hitung $>\mathrm{F}$ tabel $(34,789>2,38)$ dengan taraf signifikansi $0,000<0,1$ dengan demikian $\mathrm{H} 3$ diterima. Hal ini memberi arti bahwa karyawan PT.Telkom Sumatera menyadari bahwa kemampuan hard skill dan soft skill seseorang mempengaruhi meningkat tidaknya kinerja karyawan tersebut.

Menurut Putri Meylani (dalam Rosdanu, 2012) menyatakan bahwa pendekatan gaya hard skill saja kini sudah ditinggalkan, sangat disayangkan jika hard skill baik, tetapi soft skill karyawan tersebut buruk. Akan tetapi, Widayanti (2011) menyatakan bahwa kemampuan hard skill yang baik dan kemampuan soft skill mampu membuat karyawan bisa terus berkembang dan meningkatkan kinerja karyawan tersebut.

Menurut penelitian, kebanyakan model pendidikan akan memberikan $90 \%$ hard skill dan $10 \%$ soft skill. Sementara dalam dunia kerja soft skill lebih banyak dibutuhkan. Hal ini 
sesuai dengan penelitian di Harvard University Amerika Serikat (dalam Furham,2011) penelitian ini mengungkapkan, kinerja hanya ditentukan oleh $20 \%$ hard skill dan sisanya $80 \%$ oleh soft skill.

Saat berinteraksi dengan rekan kerja misalnya, tentu setiap karyawan tidak bisa bersikap seenaknya. Demi menciptakan atmosfer kerja yang produktif, setiap karyawan harus bisa berkomunikasi dengan baik. Atasan dan bawahan juga wajib menjalin komunikasi yang berkualitas agar ritme kerja dalam kantor tersebut tidak terganggu. Oleh karena itu sikap karyawan akan mempengaruhi kinerja. Ditambah lagi dalam perusahaan terdiri dari berbagai divisi yang saling terkait satu sama lain, dan saling bekerja sama untuk mewujudkan kepentingan perusahaan. Dengan demikian kemampuan untuk bekerja sama dibutuhkan saat bekerja apalagi bekerja dalam tim.

Para ahli menjelaskan bahwa soft skill tidak hanya diukur dari sikap dan karakter seseorang. Soft skill juga mencakup kebiasaan seharihari dan motivasi dalam diri. Sebagai contoh, karyawan dengan soft skill yang baik tidak akan terbiasa datang terlambat ke kantor. Mereka akan memilih datang tepat waktu atau justru lebih awal agar terlebih dahulu menyiapkan banyak hal sebelum mulai bekerja. Selain itu, mereka punya motivasi yang jelas dalam menjalani pekerjaan sehari-harinya. Mereka punya keinginan untuk menapaki jenjang karir dan menyiapkan masa depan. Hal inilah yang akan menandakan bahwa mereka mempunyai etos kerja yang tinggi. Jauh dari keinginan bermalasmalasan dan ngobrol saat jam kerja.
Orang-orang dengan soft skill tinggi akan sibuk mengukir prestasi.

Keberhasilan dalam dunia kerja salah satunya ditentukan oleh jiwa kepemimpinan yang dimiliki karyawan. Kemauan dan kemampuan untuk memimpin juga termasuk dalam soft skill. Bukan hanya orangorang yang memegang jabatan penting saja yang dapat memimpin. Namun, semua karyawan diharapkan punya jiwa kepemimpinan dalam dirinya. Ada beberapa tanda bahwa karyawan memiliki jiwa kepemimpinan salah satunya adalah ketika bisa mengemban tugas dan tanggung jawab yang diberikan, termasuk menyelesaikannya dengan baik.

\section{PENUTUP}

Berdasarkan hasil yang diperoleh dari penelitian ini, maka ditarik beberapa kesimpulan antara lain:

1. Hard Skill berpengaruh secara signifikan terhadap kinerja karyawan PT. Telkom Sumatera. Hal ini dapat dilihat dari pengujian hipotesis secara parsial (uji t), yaitu: Nilai t hitung variabel Hard Skill (X1) $3,428>$ dari t tabel yaitu 0,313 dan nilai signifikan $0,001<0,1$. Hal ini berarti Hard Skill secara parsial berpengaruh positif dan signifikan terhadap Kinerja Karyawan PT. Telkom Sumatera, H1 diterima.

2. Variabel soft skill memiliki pengaruh positif dan lebih dominan terhadap kinerja karyawan PT. Telkom Sumatera. Hal ini dapat dilihat dari pengujian hipotesis secara parsial (uji t), yaitu: Nilai t hitung variabel Soft Skill (X2) $4,188>$ dari $t_{\text {tabel }}$ yaitu 0,313 dan nilai signifikan $0,000<0,1$. Hal ini berarti Soft Skill secara parsial berpengaruh positif dan signifikan 
terhadap Kinerja Karyawan PT. Telkom Sumatera, H2 diterima.

3. Variabel Hard Skill (X1) dan Soft Skill (X2) secara bersama-sama mempengaruhi kinerja karyawan PT. Telkom Sumatera. Hal ini dapat dilihat dari hasil perhitungan Uji $\mathrm{F}$ dimana nilai $F_{\text {hitung }}>F_{\text {tabel }}(34,784>$ $2,38)$ dan signifikasi penelitian yang diperoleh dari hasil perhitungan sebesar $0,000(0,000<0,1)$. Hal ini memberi arti Hard Skill (X1) dan Soft Skill (X2) secara bersama-sama mempengaruhi kinerja karyawan PT. Telkom Sumatera, H3 diterima.

\section{DAFTAR PUSTAKA}

Arikunto, Suharsimi. 2006. Prosedur Penelitian, Suatu Pendekatan Praktek. Jakarta: Bina Aksara.

Babic, Verica. 2011. Pengembangan, Soft Skill dan Hard Skill: Situasi Saat Ini di Perusahaan Serbian. Serbia. Universitas Kragujevac.

Benedicta, dkk.2016.Kompetensi Soft Skill, Kompetensi Hard Skill dan Keinginan Untuk Menjadi Pengusaha dari Lulusan Kejuruan.Jurnal Internasional Belajar Bisnis Vol 9, No.2.

Chery,Novita Sari, 2012. Kontribusi Soft skills Terhadap Prestasi Kerja Karyawan PT. Lottemart Indonesia.Jakarta. Universitas Gunadarma, Fakultas Psikologi.

Eva, Dkk. 2012.Pengaruh Kompetensi dan Penempatan (Job Placement) Terhadap Kinerja Pegawai PT. PLN (PERSERO) Wilayah Aceh.Jurnal Ilmu Manajemen Vol. 1 No.1, Agustus 2012 ISSN 2302-0199

Faizal, Alam Islami.2012. Analisis Pengaruh Hard Skill, Soft Skill, daan Motivasi Terhadap Kinerja Tenaga Penjualan
(Studi Tenaga Kerja Penjualan PT. Bumiputera Wilayah Semarang). Jurnal Dinamika Dotcom Vol 3, No.2.

Fransisca. 2016. Hubungan Hard Skill, Soft Skill dan Pengalaman Kerja Terhadap Kinerja Karyawan (Studi Kasus di Perpustakaan Sanata Dharma). Yogyakarta.Universitas Sanata Dharma.

Hariyanto, Pengaruh Soft Skill dan Komitmen Terhadap Kinerja Karyawan Perusahaan di Wilayah Kabupaten Pasuruhan. Jurnal Administrasi dan Bisnis, Vol.10 No.1, Juli 2016 ISSN 1978-726X

Hasibuan, Malayu S.P. 2002. Manajemen Sumber Daya Manusia. Jakarta: Bumi Aksara.

Kasmir, 2016. Manajemen Sumber Daya Manusia (Teori dan Praktek. Jakarta: PT. RajaGrafindo Persada.

Kadek. 2016. Pengaruh Kecerdasan Intelektual, Kecerdasan Emosional, Kecerdasan Spiritual, Komitmen Organisasi Terhadap Kinerja Auditor. EJurnal Akuntansi Universitas Udayana Vol.17 No.2, November 2016 ISSN:23028556

Kholis, Azizal. 2016. Identifikasi Hard Skill dan Soft Skill Sarjana Akuntansi (Studi Empiris di Kota Medan). Jurnal Mediasi-FE.UNIMED Vol. II No. 05, Desember 2016 ISSN: 2085-6342

Mangkunegara, Anwar Prabu. 2004. Manajemen Sumber Daya Manusia. Bandung: PT Remaja Rosdakarya. 
Mumiah, Ingkan Rosdanu. 2012. Pengaruh Soft Skills Terhadap Kinerja Karyawan di PT. Binayasa Pramana Cabang Bandung. Universitas Pendidikan Indonesia.

Panggabean dan Prasetyo. 2008. Manajemen Sumber Daya Manusia. Bogor. Ghalia Indonesia.

Paisal dan Susi.2010.Pengaruh Kecerdasan Emosional dan Kecerdasan Spiritual Terhadap Kinerja Karyawan Pada LBPPLIA. Palembang. Jurnal Ilmiah Operadi Bisnis Politeknik Negeri Sriwijaya.

Ridwan, \& Akdon, 2005. Rumus dan Data Dalam Analisis Statistika. Alfabeta, Bandung.

Rivai, Veithzal.2003. Manajemen Sumber Daya Manusia Untuk Perusahaan dari Teori ke Praktek, PT. Rajagrafindo Persada, Jakarta.

Robbins, P Stephen dan Judge, A Timothy. 2008. Prilaku Organisasi. Edisi Dua Belas. Jakarta : Salemba Empat.

Rosyed,dkk. 2014. Pengaruh Kecerdasan Emosional Terhadap Kinerja Pegawai Perguruan Tinggi La Tansa Mashiro di Rangkasbitung. Jurnal Studia Manajemen Vol.3 No.3 ISSN: 2337-912X

Sailah.2008. Pengembangan Soft Skill di Perguruan Tinggi, LPPMIPB, Jakarta.

Sedarmayanti. 2007. Manajemen Sumber Daya Manusia. Bandung :PT Refika Aditama.

Siagian, Sondang. 2002. Manajemen Sumber Daya Manusia. Cetakan Ketujuh.
Siti, Sri. 2012. Peningkatan Soft Skill Tanggung Jawab dan Disiplin Terintegrasi Melalui Pembelajaran Praktek Patiseri. Jurnal Pendidikan Karakter Vol II, No.2.

Stepanus.2013. Pengaruh Budaya Organisasi, Gaya Kepemimpinan, dan Motivasi Kerja Terhadap Kinerja Pegawai. Jurnal Studia Akuntansi dan Bisnis Vol.1 No.2, (2013-2014) ISSN: 23376112

Sugiyono. 2011. Statistika Untuk Penelitian. Jakarta. Alfabeta.

Sutikno, Slamet. 2009. Pentingnya Soft Skill Terintegrasi Dalam Kehidupan Perkuliahan Dalam Rangka Mengurangi Pengangguran dan Menyonsong Era Pasar Bebas. Program Kreativitas Mahasiswa (PKM). Universitas Negeri Malang.

Tegar, dkk. 2014. Pengaruh Hard Skill dan Soft Skill Terhadap Kecenderungan Keinginan Pemilihan Bidang Kerja Melalui Kepercayaan Diri Mahasiswa (Studi Pada Mahasiswa Jurusan Manajemen Fakultas Ekonomi Universitas Jember. Artikel Ilmiah Mahasiswa.

Wahyani. 2016. Pengaruh Hard skill dan Soft skill Terhadap Kinerja Karyawan PT. Telekomunikasi Indonesia Divisi Regional I Sumatera. Medan: Skripsi Universitas Negeri Medan.

Widayanti, Rahayu. 2011. Pengaruh Hard Skill dan Soft Skill Terhadap Kinerja Karyawan PT.Telkom Kandatel Malang. Jurnal Pengembangan Manajemen Informatika dan 
JURNAL PLANS

Penelitian Ilmu Manajemen \& Bisnis

ISSN: $1978-7057$

E-ISSN: 2527-306X

Komputer Vol 3 No.3 ISSN: 2086-2653 P.62-86

Winarno, Slamet.

2010

Pengembangan Soft Skill dan

Hard Skill Dalam

Meningkatkan Kualitas

Pelayanan. Jurnal Cakrawala Vol X, No.2.
Yanti. 2010. Pengaruh Kompensasi, Motivasi Kerja, Lingkungan Kerja dan Disiplin Terhadap Kinerja Karyawan Pada CV Koperasi Puri Kencana Taxi Semarang. Junal Ekonomi, Jurusan Managemen. Fakultas Ekonomi Universitas

Pandanaran. Semarang. 